\title{
WAYANG IN ISLAMIC PHILOSOPHY
}

\author{
Yuyun Yunita \\ Institut Agama Islam An Nur Lampung \\ Email: azkianaziha4@gmail.com
}

\begin{abstract}
Wayang kulit is named after Javanese wayang which means shadow or taken meaning that wayang is a depiction of life or a reflection of the various human traits found in various souls of the human conscience itself. The universe itself is divided into various types into two basic traits such as wrath and kindness. The history of the story of Dewa Ruci as one of the puppet plays is a cousin of the many ways and rich in philosophical values of religious diversity that is so profound. The history of this story depicts a man or man who has a lot of strong will to find the best ways that can be considered to bring people to happiness. In the search for happiness, it is not easy to do because it will be many and there are obstacles or prevention that may be faced by many. This is where the aesthetic value or beauty is packaged and wrapped up in the history of the gods of Ruci and becomes the first and foremost doctrine of the conception of the divine, humanity, and respect of the human beings with the creator or than. the story of the goddess Ruci outlines or philosophically symbolizes how human beings must go through and make an inner journey to find their true identity or look for paraning dumadi the origin and purpose of life in human beings or tackle the human gusti, the conception of God and how humans lead to God, the wayang kulit is very much, the art of wayang puppets cannot be retracted from history, which the bags are retold through wayang.
\end{abstract}

Keywords: Pupet Play And Divinity

\begin{abstract}
Abstrak
Wayang kulit dinamai sesuai dengan wayang Jawa yang berarti bayangan atau diambil artinya bahwa wayang adalah penggambaran kehidupan atau refleksi dari berbagai sifat manusia yang ditemukan dalam berbagai jiwa nurani manusia itu sendiri. Alam semesta itu sendiri dibagi menjadi berbagai jenis menjadi dua sifat dasar seperti murka dan kebaikan. Sejarah kisah Dewa Ruci sebagai salah satu lakon wayang adalah sepupu dari banyak cara dan kaya akan nilai-nilai filosofis keanekaragaman agama yang begitu mendalam. Sejarah kisah ini menggambarkan seorang lelaki atau lelaki yang memiliki banyak kemauan kuat untuk menemukan cara terbaik yang bisa dianggap membawa orang menuju kebahagiaan. Dalam mencari kebahagiaan, tidak mudah dilakukan karena akan banyak dan ada kendala atau pencegahan yang mungkin dihadapi banyak orang. Di sinilah nilai estetika atau keindahan dikemas dan dibungkus dalam sejarah para dewa Ruci dan menjadi doktrin pertama dan terpenting dari konsepsi ilahi, kemanusiaan, dan rasa hormat manusia dengan pencipta atau dibandingkan. kisah dewi Ruci menguraikan atau secara filosofis melambangkan bagaimana manusia harus melalui dan melakukan perjalanan batin untuk menemukan identitas sejati mereka atau mencari paraning dumadi asal dan tujuan hidup manusia atau menangani manusia gusti, konsepsi Tuhan dan bagaimana manusia mengarah kepada Tuhan, wayang kulit sangat banyak, seni wayang tidak bisa ditarik dari sejarah, yang tasnya diceritakan kembali melalui wayang.

Kata kunci: Permainan Wayang dan Keilahian
\end{abstract}




\section{A. Introduction}

Wayang is a part of an old cultural expression of the Indonesian state that according to the story, found in $861 \mathrm{M}$ in Jayabaya kingdom in Mamenang Kediri. Therefore, for Indonesian people precisely in Java (west, Central, and east) is not escaped from the puppet show to be the structure of its life. Wayang is recognized as a culture of exhibition that Edipeni-Adiluhung, which means the exhibition in which there is a positive matter of beauty and charge the teachings of deep spiritual moral. Through puppet show, in the sense of good behavior and useful high for the creation of character building all of them become a good lesson for people and society. Through the Wayang exhibition, the lack of good things and the failure of the art is now again in the life of the civilization of the cultural art of our country Indonesia, slowly will be eliminated to refer to the real direction of potential regional art that means important to us and a big useful for the actors who will bring the best way. ${ }^{1}$

The learning of religious Islam is a race to give birth and produce the ability of students who have a character and Islamic religious characters and do not escape the various mistakes and deficiencies of students and girls in Islamic learning. The ever-present and undisputed, good and well-established resources that spur only for the control of the nation's bureaucracy in today's Islamic learning. ${ }^{2}$

Wayang is a Javanese traditional art culture that is still present and sustainable, is still appreciated by the community, and gives a sign of Kehidpan. Puppet can also be divided into one-Satnya artistic inheritance that has moral and very high values. Wayang Kulit is one of the historical relics in the past one of the various cultural heritages in Indonesia that still can still be upright and straight and become good entertainment and still be liked by Javanese and made good entertainment and still have good things according to Javanese people. ${ }^{3}$

The continuity of the tradition of puppet plays in our country has a good praise and flattery and the UN Council issued an opinion of praise is actually puppet plays is a great craft of making throughout the entire kingdom. Good habits that are a puppet show is still a part that lives in Javanese culture. Wayang Kulit, as a great culture like life, as well as other exhibitions, almost undergo displacement or material to be the difference and change of indigenous social culture and state.

An example of a large sample of tourism that carries a change in form dimension or formation, dimension of space and time, and cultural review of good exhibition culture such as puppet. From the opinions of some experts from Wayang, the division of the Authority certainly produces a good artwork and

\footnotetext{
${ }^{1}$ Cahya, "value, meaning, and symbol in Wayang Golek puppet Show as a representation of the Media of the establishment of the ethics" (2016), p. 118.

2 Darori Amin Islam and Javanese Culture (2000), p. 178.

${ }^{3}$ Asrul Anan and Siti Jawariyah, "Analysis of Islamic education values in puppet character Punakwanan" (2017), p. 327.
} 
more advanced or cultural wrapped neatly with some characteristic characteristics such as: (1) A mock of the original or its origin, (2) a short varied or clear solid, (3) Full of varied innovations, (4) The values of nobility, symbolically and miracles of the magic are deposited or set aside, (5) cheap The reach of the purchase.

Purwa Leather puppet show shows the Lakon that is based on a brief history of the Mlai of the true stories of the Gods, Prophets, DJs, and natural man in the first early civilization, on a tsp of the story from the Toral Lokapala, Arjunasasrabahu, Ramayana and Mahabharata. This Purwa wayang puppet is up about philosophical morality that can be used into a measure until the distance of Javanese art. Wayang Purwa Leather Puppet is also a business of the results of the original Javanese people that spread through the idea that best relates to the events of the relationship of life relationships with other communities, people with nature, and society with the creator. The origin of this Purwa leather puppet is famous around human beings, because in it there are figures, events, and a background that is done in accordance with the will of the author, in this case a mastermind or director. It concerns the values of human life and Javanese art, such as religion, arts, culture, language and literature, the philosophy of wayang intelligence skills also is the media of the nation as a cultural art performance that attracts wayang puppet can unite the different tribes in Indonesia. 4

\section{B. Discussion}

The guidance points that there is a puppet show in the puppet show through the cast and the Alrnya have authority in teaching and parenting to explore the nature of the state. Therefore wayang has become a result of a wealth of Indonesian traditions, it should be developed and used as a utilization in presenting State art that will be the result of the Indonesian people until the time is. The results of philosophers contained in the puppet always invite the community to do good and avoid evil, and to instill the spirit of "Amar Ma'ruf nahi mungkar" or the term in the puppet "Memayu hayuning great Bebrayan", according to the teachings of religion and beliefs of each. In the story of this puppet that is exemplary is the role of the character Sri Rama and Arjuna who has the nature of always promoting truth and justice, in its immaculate appearance, full of smiles, the language is subtle, the behavior is measurable and seems to be uninterested to make people difficult to anyone. The leadership role of Aordinary personage who is also exemplary, because of the time he became a ruler in the land of Astina always loved and paid attention to his people, has a

4 Darmoko, "Javanese morality in the Purwa leather puppet review on the Lakon Semar" (T.T.): p. 119. 
strong and consistent personality, has a high visionary and integrity, so that he is loved and trusted by his followers. ${ }^{5}$

\section{Meaning of type in Wayang}

Puppet show is not merely entertainment, but puppet show has a deep meaning. In pre-Islamic times, puppet is interpreted as a shadow of ancestral spirits. When Islam enters Java through Wali Songo, puppet Puppet is no longer intended as a reflection of the spirit of the ancestors because according to Islamic teachings it is a prohibition 7 because it is regarded as a form of shirk. Further explained that since the time of Wali Songo also puppet is intended as a symbol of human character. As an example is the puppet figure Buto Cakil which is a symbol of the character spiteful, envy, Jahil, his face is red as a symbol of the character is angry, the eyes are squinted like a date of a young moon called a calendar currency or a kriyipan, symbolizing a spiteful character and less open. The mouth is wide open, the lower jaw is up to the nose. ${ }^{6}$

\section{Meaning of type in Wayang}

Puppet show is not merely entertainment, but puppet show has a deep meaning. In pre-Islamic times, puppet is interpreted as a shadow of ancestral spirits. When the mouth of the Cakil as a type of arrogant character, many talk about things that are not good. Likewise, with other figures, Bima figures such as high size and big impressive, sturdy, mighty and tough. Bima type of abstinence character, honest, straightforward, decisive and brave because honest and true. His face to bow and black symbolize the nature of sincerity, honesty, and tranquility, his eyes Thelengan (whole round) effectively and bold, dressed modestly and not wearing a lot of jewellery that gives a straightforward and simple sense of character. Bima also wore a poleng cloth (a two-color box motif of black and white) that is memorable and magical. Every form of puppet figure is an image or a type of Temperai, character and Bob. The type implied in the form of each puppet figure and this pronunciation is called Wanda and Antawecana. Wanda and Antawecana. Islam entered into Java through Wali Songo, puppet Puppet is no longer intended as a reflection of the spirit of the ancestors because according to Islamic teachings it is a prohibition because it is considered a form of shirk. Further explained that since the time of Wali Songo also puppet is intended as a symbol of human character. As an example is the puppet figure Buto Cakil which is a symbol of the character spiteful, envy, Jahil, his face is red as a symbol of the character is angry, the eyes are squinted like a date of a young

5 Otok Hermawan Marwoto, "Islamic values in Wayang kulit makes an important role in the development of Islamic Arts in Indonesia" (T.T.), p. 82.

6 Sri Mulyono "puppet and Philosophy Nusantara" (2002), p. 16. 
moon called a calendar currency or a kriyipan, symbolizing a spiteful character and less open. The mouth is wide open, the lower jaw is up to the nose. ${ }^{7}$

\section{Puppet Research Method}

The channeled research in this design is quantitative research. Material Data obtained from the study of the literature books such as The Wayang Encyclopedia, Panakawan Yogyakarta and several journals discussing Punakawan in the iconography and as a medium of education in the language Hall, BPNB and Sunarto collection (academics and book writers). The interview was conducted by the group (Pengangeng Kraton Yogyakarta), Aris Wahudi (Kajur Pedalangan ISI Yogyakarta), Sunarto (Senior faculty Kriya Kulit ISI Yogyakarta), Edi Suwandha (Chairman PEPADI), Karbit Art and Film culture department Yogyakarta, the caretaker measure puppet, several puppeteer and Wayang observer in Yogyakarta. Ask for a view on the meaning of Punakawan characters and physical characteristics. Observation is done at Kekayon Museum and several puppet shows that are scattered in Yogyakarta area such as Yogyakarta Sultan Palace in Sasana Hinggil, Pendapa Cultural Office and others. Questionnaires were conducted to support data from Target audience (TA) of 48 participants, which were spread online according to the criteria TA and people sample consumer journey. Questions are asked to learn insights about Punakawan and their participation in cultural preservation. Data collection and processing takes place from the beginning of February until the end of May 2016. Analyzed using SWOT and 5W1H with iconography theory-Iconologierwin Panofsky and Hermeneutika Paul Recouer who supported the cultural theory and communication of visual research continued and deepened the previous process, by reading the sources of relevant studies and meeting with a variety of competent speakers. The design process begins with crafting ideas of materials and problems, in the form of material and visual ideas. Interpretation and hermeneutics are used in the material processing so it is suitable for the target audience. Ethnic and a elements may be included in visual terms, although the approach is quite modern. The thing that is quite a highlight is how to bring the material closer to the target audience. The authors seek it by taking the case that the target audience is often responded to with Punakawan material. It is a personified person who represents the personality of today's young generation. What is not less important is the process of media publication when it is completed. Consistency becomes key to taking attention of target audience. Social Adminmedia who plays as a figure Punakawan also have to be responsive, so that the target audience who have been interested can continue to follow the development of the publication. ${ }^{8}$

\footnotetext{
7 Dessi Stifa Ningrum, "The role of Punakawan character in Wayang Kulit as a Media character planting in the village of Tulun District, district of Indonesia, Blitar" (T.T.), p. 3 - 4.

8 A. M. Arif, "Visual communication planning for the personality of Wayang Kulit, Yogyakarta, and his physical characteristics" (T.T.), p. 93.
} 
It has been long since the Punakawan figures (both individually and simultaneously) appear as a brand of various products for the community (food, health and household needs), delivery of messages (posters for community services, glass paintings, comics), promotional means (advertising products and services) and so forth. As the picture above was made to remind the public, so as not to be greedy when occupying a position (either as a government official, tutor or community leader). It was made as a glass painting depicting the character Petruk to be king (Petruk Dadi Ratu) with the Javanese alphabet headline which means Ojo Dumeh (do not greedy) as a medium of presenter Punakawan message can be present in various media, while in Indonesia still has one television station (TVRI) then Punakawanyang character portrayed by the Alm. Ateng and friends were present through the show ' Ria Jenaka ' which had survived for 15 years. They can convey social criticism, counseling, and even discuss social issues that are again warm at the time of itu8Jaman constantly changing, nowadays has many private television stations, Punakawanpun still present with a different technical, one of the private television stations every Sunday aired a series of Punakawan animation produced by Jogjakartoon, Jogjakarta. Similarly, other private televisions continuously display leather puppet performances every weekend, and Punakawan was present in the session of Goro-Goro with the topic of problems that are more warm at the moment, even invites dialogue with the audience. Because of the difference in segments, then for Punakawan which is shown in the form of animation more discuss the problems that often faced by children (more about the problem of kindness, virtue and truth) that is more digestible by children. It shows that Punakawan can communicate with all walks of life, age and education. Along with the rapid development of multi-media technology, it will be easier to deliver the intentions and objectives of the Punakawan leaders, such as the animation company Jogjakartoon, in addition to cooperation with multinational companies and its works aired by one of the national private television stations, they also produce it in the form of VCD chips. Punakawan people are also considered effective to convey the advertising message of both products and services (Punakawan philosophy is considered relevant in all times. ${ }^{9}$

Wayang and ethical norm Puppet is actually not known only by Javanese people, although according to an expert from the West named Brandes said that Wayang is typical Javanese. As stated above, Javanese people know the world of puppet. It can even be claimed, the world of Puppet is the world and the distinctive culture of the Javanese people because wayang his characters is a picture of life and ethical norms with all the multidimensionality of Javanese people. Wayang is also a picture of a concrete human life with all the characteristics of unique characters that exist in a variety of individual human,

\footnotetext{
${ }^{9}$ Selu Margaretha Kushendrawati, "Puppet and ethical Values: a picture of the Javanese attitude of life" (T.T.), p. 109.
} 
participatory. The inner smoothness manifested in the prudent behavior or behavior the cradle of the wrath of the inner beauty can be revealed and reflected in the Javanese puppet figures. So talking about wayang means talking about humans or Javanese people. In the Mahabharata story, for example, the Kurawa is symbolised as a force the cradle of Wrath while on the other hand Pandawa is always a reflection of the power of noble traits, fair, good and such. As is commonly known, puppet stories such as the Mahabharata epic and Ramayana are originally from India. But through some kind of initiation then puppet stories are changing and become a special culture of Indonesia especially Java beside there are various forms of puppet such as Wayang Golek, Wayang orang, puppet Potehi, Wayang Krucil and others. But the most popular form in Java is wayang kulit. Wayang Kulit is taken from the classic story of Purwa puppet. While Wayang Purwa plays mostly taken from the material stories derived from the stories of the Mahabharata epic, Ramayana and the spate of both through the contextualise become as we now see. Therefore, epic like Mahabharata, Ramayana originating from India as in reality clearly appears a fundamental difference in manifestations with in Indonesia. For Javanese puppet stories symbolize human behavior and character in achieving the goal of life both born and inner. In a puppet performance, viewers can get to know ethical teachings about what is good and what is bad. The actions of each puppet figure in certain plays are often used by Javanese people to understand the meaning of life or various concrete reality. Puppet performances especially leather puppets are always loaded with certain missions, essential moral values such as the relationship of affection between parents with children, loyal state, responsibility to the environment, and others. For example, it is illustrated in episodes. ' Karna died, when the goddess Kunti cried and banned her son not to go to Kurusetra field against her own brother, namely Harjuna. Because if Karna fought against Harjuna surely he would lose. But the request of his mother was rejected because of Karna loyal to Duryudana (which although Duryudana was an antagonist) who had given him the welfare and life worthiness while the mother himself had thrown it away because of the shame of having a child cheating with the god Surya and his own siblings/Pandawa also mixed him. In the story can be learned the meaning of a loyalty, a sense of allegiance to the state of a real rational Karna. In this case Karna can clearly demonstrate an ethical personality to the goodness of Duryudana regardless Duryudana is the enemy of his own mother and siblings. ${ }^{10}$

Wayang has a strong influence and the favored people of Indonesia, almost all of Indonesia know the puppet. Wayang is a dominant culture for Indonesian people and is a part of the sublime cultural heritage of the nation. History shows that wayang as a culture is experiencing development and integrating with local cultures and flavours. So it develops by itself ranging from

10 Bing Bedjo Tanudjaja, "Punakawan as Visual efficacy Media" 6 (2004),p. 44. 
the form, variation, and performances of puppet in such a way to be interesting and easy to understand by society. In conveying the mission and objectives, such as Da'wah or counsel in the form of philosophical admonitions, as well as the moral values of a puppeteer let him through one of the wayang kulit characters, Punakawan characters, where punakawanis the characters in the form of strange and funny puppet, including also the character and behavior of his pattern. Punakawan, consisting of four figures namely Semar, Gareng, Petruk and Bagong with various characters unique in it. The method of research implemented is quantitative method of quantitative is a method initiated to understand the phenomenon of what has passed studied with a natural context 11

This person is often used as the symbol of an ideal figure who has a humble nature, likes to help others, is not greedy, does without, reduces food and sleep, and performs other practices. Human traits in Javanese mythology are often symbolized by the nature and character of the characters in the puppet world. What happens in the world of puppet will happen in the real world. As if what is happening in the puppet story depicting a real state of things, both already happened and that will happen.12

A researcher in implementing a study should understand, and understand in implementing a research method. According to Sugiyono the research method is a scientific way to get data with specific purpose and usability. In the research method there are several components that are approaches and types of research, the presence of researchers, site researchers, data sources, data collection procedures, data analysis, checking the validity of the findings and the stages of research. According to Moleong qualitative research is a study used to understand the phenomenon of what is experienced by the subjects of research holistically by means of descriptions in the form of words and language a special context by utilizing various scientific methods. This research uses a qualitative approach of the research Descriptionbecause researchers want to see and describe the phenomenon that occurs in wayang kulit shows by puppeteer Ardianto in Bendosewu village, the district of Blitar, which is related to the way of planting Punakawan character in the community. With a qualitative approach this type of descriptive researchers collect and discredit the data obtained thoroughly. ${ }^{13}$

How is the puppet character Punakawan in the puppet Punakawan (Ponakawan, Panakawan). Punakawan is derived from the word puna which means understand, and friend who means friends (Warih Jatirahayu and Suwarna Pringgawidagda,. In another sense, as expressed in the Sabangangit's web, Puna or pana in Javanese terminology means to understand, light, clear,

11 Priyanto "To know the values of the leadership of nobility in puppet show" (2019), h. 3.

12 Asrul Anan and Siti Jawariyah, "Analysis of Islamic education values in Wayang character Punakwanan," (2017),h. 336.

13 Dessi Stifa Ningrum, "The role of Punakawan character in Wayang Kulit as a Media character planting in the village of Tulun District, district of Indonesia, Blitar" (T.T.), p. $3-4$. 
careful, understand, astute in noticing or observing the meaning of the nature behind the natural events and events in human life. Meanwhile, friend means tutor or friend, who has the ability to observe, analyze, and take on all phenomena and events of nature and events in human life. Punakawan can also be interpreted as a nanny, a mentor who has an intelligence of thought, inner acuity, akal-budi ingenuity, broad insight, thoughtful attitude, and expedient in all sciences. Speak trustworthy, and the same words and actions are not contradictory. Javanese cultural treasures refer to it as "responsiveness ing sasmita. "Punakawan" In general consists of four characters with a unique character. There is Semar, Petruk, Nala Gareng, Bagong. Having an existing character, Semar is described as a wise human being and rich in knowledge of both the naked eye and the unseen, and has a great contribution to his master through the admonitions presented, although sometimes with a style of kidding. Meanwhile, Gareng is a figure who is not proficient in speaking even though it actually has extraordinary, erdic and clever thoughts. Gareng's results are more often the characters behind the scenes with his ideas that are run by others. Another character, Petruk, has a character that does not have the advantage of anything but a lot of nonsense. As for the bagongs, he is more in the shadows of Semar, intelligent in conveying criticism through the humorous humor, may be likened to the figure of Abu Nawas or Nasrudin in the stories of Sufi humor.14

Sunan Kalijaga is believed as the creator of the Punakawan figure as one of the efforts to spread the religion of Islam in the land of Java, he also uses the implied nature of it in carrying out the activity so that his mission can be done in a good way. It certainly attributes the name of the character adapted to the objectives and characters concerned. In Javanese puppet stories, they are divided into two groups which each have the same role as spiritual and political counselors, but each nurture a character whose characters contradict each other. First, the group Ki Lurah Semar Badranaya. ${ }^{15}$

\section{Study}

Public information is information that is created, compiled or attempted by the government. Here public information is intended as information required by the people, managed based on the trust of the people by the Government and already should be available to the interests of the people, unless otherwise stipulated by the laws and regulations. In this limitation, the people have the right to the information produced by the government agencies, with the requirement that the exclusion of the abandonment of the people's rights can only be done based on the provisions stated in the laws and regulations. In this kind of concept, clear public information is an important aspect in the

14 Burhan Nriyanto, "puppet and character development of the Nation" (2011), p. 27.

15 Bayu Anggoro, "Puppet and Performing Arts: Historical Study of the history of the art of Wayang Ditanah Javanese as the art of Preaching" (2018), p. 127. 
implementation of democratic State as the right and obligation of all elements of the nation. ${ }^{16}$

The study of cultural puppets in Indonesia is one of the areas that show Wayang puppet as a culture that means a wide meaning of the release marks or attitudes that are shown in the real world. Culture of function that is great for people and human environment of all kinds of strength that must be overtaken by many people is the power of nature. It could be big because the Puppet is very exotic for Javanese custom. ${ }^{17}$ Community rights to their own freedom of information can actually be seen from two approaches. Through the approach of public accountability, information freedom is the obligation of the service or public agency to disseminate the products of policies, rules, plans and results of its wealth and humidity to the wider community; and the rights of society to know the policies, rules, plans, and outcomes as a knowledge to follow the implementation of a transparent state and patterned feedback. Meanwhile, in a socially responsible community approach, freedom of information is a broad community obligation to provide data and information about itself or its institution correctly and completely, and the right of service or public agency to acquire it as a thorough development material. In this context, either the agency or the public body has the right and obligation to realize the implementation of healthy information. Both approaches above demonstrate the needs of the pranata and the role of service or public agency to provide public information to the community to the fullest. However, the provision of a clear public information system will be very beneficial for our country as an indication of the country running the democratic government consistently.

Public information includes: first, information about national policies that have a wide impact and influence on community life, therefore known and understood by society. Second, the information needed by the community as an explanation of the emerging issues in society. Public information is information that is generated, managed, owned, assembled, or mastered by a public body in connection with the duties, functions, and authorities that are executed and viewed on that body and have a direct or indirect impact on people's lives. ${ }^{18}$

Puppet art was originally developed by the Brahmana people as the media broadcasting of Hinduism, around the IV century CE with reference to the two great books of Ramayana and Mahabharata. However, this opinion gets a disclaimer with the existence of a dugaanthat the puppet is considered to have existed in the land of Java long before the Hindu religion came to the archipelago. As for the figures that are often known in the world of the crossing such as Petruk, Semar, Gareng and Bagong are not part of the original story in

16 Kanti Walujo, "the spread of Wayang and public information dissemination" (T.T.), p. 146.

17 Sulhatul Habilah "Study of Cultural studies on the Bima puppet Show Ontology Perspective" (2003), p. 178.

18 Masroer Ch. Jb, "Islamic spirituality in the culture of Javanese Sundanese leather Puppet Society" (2015), p. 50. 
the Book of Ramayana and Mahabharata but the original story from Java. Brief History of Wayang, accessed through in the context of West Java, the puppet first developed in Cirebon, precisely during the time of Sunan Gunung Jati around the 15th century AD. In the early 16th century in West Java began to be introduced type Wayang Golek slab or Cepak. Basically, people know this type of puppet with the name Wayang Purwa, namely as the artificial puppet that is in the flow.

The form of performances demonstrated by the mastermind selection participants gives an idea that in the identity of the process of encounter and negotiation. The collective style is understood as something that loosely adopts the personal identity. In that looseness there are endless choices. It is no longer possible to formulate a kind of fixed essence of identity, because the identity is more as a result of the process of contestation-while against the other, not a fixation. This is what the participants of the professional puppeteer selection Yogyakarta. Although it remains within the Yogyakarta-style corridor, but individual freedoms still emerge as an important factor, as shown in the first Kasidi theory that the mixing or crossword style is currently flexible. People no longer care whether that is displayed or seen comes from a style in its own community or from another community. This kind of fact has been noted by Umar Kayam as an important fact in the case of the style boundary until the formation of a new order. ${ }^{19}$

Wayang is an ancestral cultural heritage that has been estimated to have existed since \pm 1500 year BC. Wayang as one of the performances is often interpreted as a shadow that is unclear or vague, moving here and there. The faint shadow is interpreted as a depiction of human growth. In Indonesia, especially in Java, there are hundreds of puppets that can be classified according to the story, how to show Puppet, and the material used to make wayang. About half of the number of puppets is now not performed anymore, even among them are extinct. Among the most major performances and still present is the wayang kulit in Central Java. The popularity of wayang kulit is solid with philosophical, pedagogical, historical, and symbolic values. ${ }^{20}$

The claims of antiquinity authenticity are always attributed to puppet theaters around the world, especially by those who seek to link from heritage institutions, financial inclusion of the tourism industry, or legitimacy, at the time of responding to a diminishing audience. However, all that we know about puppet theater indicates that in reality, the tradition is never static but it is continuously adapted for contemporary audiences with ever-changing performance contexts. Even the forms of puppet Theater at a glance appear stagnant or ' toss ', as marionette performances are displayed on public holidays

19 Bambang Slanjari, "the ideology and identity of the puppeteer in Yogyakarta professional Selection" (2017), h. 188.

20 Bayu Anggoro, "Puppet and Performing Arts: A History study of the historical development of Wayang puppet art in Java as the performing arts of Da'wah,", 2, 2018, p. 124. 
in America, Japanese-subsidized Bunraku society, or the theater of Shadows that are always staged in relation to rituals such as the Tógalugómbeata in India (Singh,1999), in fact, are always updated and revamped in sometimes subtle, sometimes dramatic ways. Innovation is not the opposition of tradition; The change is necessary to keep the tradition vital and meaningful as emphasized by sociologist Edward Shils years ago. ${ }^{21}$

\section{Conclusion}

Based on what was conveyed in the material above I concluded in the role of the revelation of the position of the Punakawan so very important and prominent than others have been faithful to accompany Janaka in the journey. Punakawan is a symbolism of the karsa, copyright, taste and work turned into a human culture of wayang message was delivered during Goro-Goro when the title of the man Semar.The various aspects above, there are several sophisticated research methods to examine and observe the plays and also the studies that are used to study the various things carried out also the results of research and study as evidence of good and correct observation results. Wayang as depictions of old historical life, controlled by a mastermind tell about events such as the Brahmin story. Although the Puppet is an ancient Javanese tradition Lakon wayangpun many like it because of the interesting storyline and good story to experience. Wayang is a symbol of Javanese culture that can relate to Islam.

\section{Reference}

Cahya, "value, meaning, and symbol in Wayang Golek puppet Show as a representation of ethics" (2016)

Darori Amin Islam and Javanese Culture (2000)

Asrul Anan and Siti Jawariyah, "Analysis of Islamic education values in Wayang Punakwanan character" (2017)

Darmoko, "Javanese morality in the Purwa leather puppet review on the Lakon Semar" (T.T.)

Otok Hermawan Marwoto, "Islamic values in Wayang kulit makes an important role in the development of Islamic Arts in Indonesia" (T.T.)

Sri Mlyono "puppet and Philosophy Nusantara" (2002)

Dessi Stifa Ningrum, "The role of Punakawan character in Wayang Kulit as a Media character planting in the village of Tulun District, district of Indonesia, Blitar" 9 (T.T.)

A. M. Arif, "Visual communication planning for the personality of Wayang Kulit, Yogyakarta, and his physical characteristics" (T.T.)

Bing Bedjo Tanudjaja, "Punakawan as Visual efficacy Media" (2004)

Priyanto "To know the values of the leadership of nobility in puppet show" (2019)

${ }^{21}$ Matthew Isac Cohen, "Wayang Kulit Tradisional Dan Pasca Tradisional Dijawa Masa Kini" 01 (2014), p. 11. 
Sulhatul Habilah "Study of Cultural studies on the Bima puppet Show Ontology Perspective" (2003)

Burhan Nuriyanto, "Wayang Dan character Development Nation" (2011).

Bayu Anggoro, "Puppet and Performing Arts: Historical Study of the history of the art of Wayang Ditanah Javanese as the art of Preaching" (2018).

Kanti Walujo, "the spread of Wayang and public information dissemination" (T.T.): 146.

Masroer $\mathrm{Ch}$. Jb, "Islamic spirituality in the culture of Javanese Sundanese leather Puppet Society" (2015)

Bambang Slanjari, "the ideology and identity of the puppeteer in Yogyakarta professional Selection" (2017)

. Matthew Isac Cohen, "traditional Javanese puppet and traditional post in present-day Java" (2014).

Selu Margaretha Kshendrawati, "Puppet and ethical Values: a picture of the Javanese attitude of life,".

Barnas Sabunga, Dasim Budimansyah, Sofyan Sauri, "character values in Wayang Golek Purwa puppet Show" (2016).

Wisma Nugraha, "role and function of the people of Semar-Bagong in the Pagelaran of the East Java style leather Show" (2003). 